\title{
A TUDÁSAlAPÚ gAZDASÁg ÉS A GLOBALIZÁCIó ${ }^{1}$
}

\section{BEVEZETÉS}

„Politikusaink gyakorlatilag ismerik az elmúlt harminc év Kínáját - azonban még ez a nagyon korlátozott tudás is hiányos és gyakran felületes. Hiányzik belöle a történelmi mélység. Ennek eredményeként a jelenlegi (tudásunk?) Kínáról a közel kétezer éves kereszténységen, ennél is inkább a három évszázad óta tartó európai és észak-amerikai felvilágosodás eszméjén alapszik, valamint a jelenkori kínai kapitalista gazdaság tapasztalatain nyugszik. Ha ugyanezek a mércék alapján vizsgálnánk az olyan ókori civilizációkat, mint Mezopotámia, az egyiptomi kultúra, maják és az inkák, a görögök és a rómaiak, egyik civilizáció sem tudná megállni a helyét tudálékos erkölcsi és politikai ítéletünk elött. Mivel ezek a kultúrák mind elpusztultak, kedvezőtlen megítélésünk elől megmenekültek. Ezzel szemben a kínai kultúra nem halt meg. Nagy változásokon ment keresztül 4000 év alatt, de mindannyian tudjuk, hogy életereje sértetlen. Ez egy elképesztő folyamat, ha az emberi történelem minden más magas kultúrájának történelmével összevetjük." [Schmidt, 2010: 292-293.]

Helmuth Schmidt 2010-es cikkében a globalizáció egyik lényegi vonását ragadta meg Kína felzárkózása kapcsán, a magaskultúrák egységesülését. Azt az intézményi rendet, technológiai és gazdasági keretet, amiben jelentős, fegyveres összecsapásokig terjedő konfliktusok nélkül fel lehet dolgozni és hasznosítani lehet más kultúrák és civilizációk eredményeit, és a világ egységes irányításához szükséges politikai, gazdasági és kulturális feltételeket meg lehet teremteni. Ezt nevezzük globális kormányzásnak, ami a globalizáció jelenlegi korszakának meghatározó tendenciája.

A globális kormányzás feltétele az értékrendi egység, ami a magaskultúrák, vagy talán már helyesebb egyes számban, magaskultúrának nevezni, sajátja. A magaskultúra lényege az egyetemes emberi értékrend, a biztonság, szabadság, demokrácia és jólét alkalmazása, és ebben közös a mezopotámiai, az egyiptomi, a görög, a római, a keresztény és a kínai kultúra is. Az értékrendi alap tekintetében különböznek a magaskultúrák a szubkultúráktól, amik az elzárkózást, az elidegenedést képviselték és képviselik, és amik feleslegesnek, szubjektív döntésnek tartják az értékrendet és az arról való beszédet. Ilyen szubkultúra a neoliberalizmus, ami az elmúlt harminc évben jelentős szerepet kapott a közbeszédben. A neoliberalizmus volt az, amelyik Kínára csak kapitalista országként tekintett, és elegendőnek látta bevonását a világgazdaságba világpolitikai szerepvállalás nélkül. Ezt a felfogást utasította el Schmidt, amikor amellett érvelt, hogy Kína lényege nem a kapitalizmus, hanem a magaskultúra.

\section{TANULÁS ÉS GAZDASÁGELMÉLET}

A tanulás mint fejlődési keret a gazdaságelméletbe is bekerült, és ennek egyik fontos dokumentuma Bruce C. Greenwald és Joseph E. Stiglitz közös munkája, „A tanuló társadalom megterem-

\footnotetext{
${ }^{1}$ Ezúton szeretném megköszönni Jankowski Rita segítségét a cikk elkészítésében és gondozásában. A KözGazdaság 2017 novemberi számában megjelent Mihályi Péter recenziója a kötetről. A téma fontosságára való tekintettel úgy gondoltuk, hogy a kötetet egy másik szempontból is szeretnénk megvilágítani, és ezért közöljük ezt a könyvismertetöt.
} 
tése”. A szerzők kimondott célja egy új, hosszú távú gazdaságpolitikai irány támogatása. „Ezért a tanuló társadalom megteremtését a gazdaságpolitika egyik legfontosabb célkitüzésévé kell tenni." (22. o.) Bármennyire közhelyszerünek is tűnik ez a közelítés, egyáltalán nem az. Greenwald és Stiglitz ugyanis egyértelmủ a tekintetben, hogy a tanulást nem a piac teremti meg, hanem a gazdaságpolitikának kell úgy alakítania az egyes gazdasági intézményeket, hogy azok tanulásra ösztönözzenek. Ez gazdaságpolitikai fordulat a korábbi neoliberális felfogással szemben, mert ott a tanulást eszköznek tekintették a profit és a haszon elérése érdekében. A nyeréshez a versenyben szükség volt tudásra és tanulásra, és ebből fakadóan a fejlődés és növekedés lényege a nyerés, és nem a tudás maga.

Greenwald és Stiglitz elméletének megalapozását filozófiai eszközökkel is el lehetne végezni, és ez is hozzájárulhat a hosszú távú gazdaságpolitikai fordulat tartalmának megvilágításához. Már Arisztotelész is azzal kezdte Metafizika című munkáját, hogy „minden ember természeténél fogva törekszik a tudásra." [Arisztotelész, 1992, 980a 21]. Az ember lényege az ókori görög hagyomány alapján a tudás megszerzése, ettől tekinthető embernek, és nem attól, hogy önző, haszon- vagy profitmaximalizáló. A gazdaságpolitika használhatja a profitmaximalizálást arra, hogy ösztönözze a tudás megszerzését, de ez csak átmeneti forma, eszköz, a nem-emberi állapotból való kiemelkedés egyik lehetséges módja. Az ösztönzés eredménye a tanulás a tanulásért, „a tanulva tanulni a tanulást" (23. o.), amikor a tudás és a tanulás ad intézményi formát a politikai, gazdasági és kulturális cselekvésnek.

A tanuló társadalom, ami egybeesik a tudásalapú társadalommal, a fejlődés kerete, és ez a másik elem, ami megkülönbözteti a könyvet a neoliberális közelítéstöl. A fejlődés fogalmának középpontba állítása, a fejlődést segítő, ösztönző intézmények kutatása minőségi ugrás. Az 50-es, 60-as évek közgazdaságtanában még jelentős szerepet játszott a fejlődés kategóriája, de a '70-es évektől kezdve az egyensúly kiszorította a fejlődés fogalmát, majd a 90-es évektől a növekedés vált elsődlegessé. A 2000-es évektől kezdték megkérdőjelezni a növekedés fogalmát, vetődött fel az a probléma, hogy mi a célja a növekedésnek. Ezzel elkezdődött a fejlődéselméletek reneszánsza, a fejlődés értelmezése.

Az ebben az időszakban született első közelítés Amartya Sen-é volt, aki a szabadságot tekintette a fejlődés mércéjének, majd a 2010-es években ezt egészítette ki a várható élettartam, és általában az egészség, mint fejlődési keret. [Sen, 1999], [Deaton, 2013] Mind a két közelítés ugyanarra az alapra vezethető vissza: az értékrendi meghatározásra és annak alkalmazására, konkrét anyagi célként való meghatározására. Amartya Sen közvetlenül az értékrendi alapot jelenítette meg. Deaton, illetve más szerzők ennek alkalmazását végezték el azzal, hogy az egészséges életmódra [Fogel, 2004], vagy az egészségügyi ellátórendszer stabilitására tettek javaslatot. Greenwald és Stiglitz ezeket a koncepciókat fejleszti tovább azzal, hogy a tág értelemben vett oktatás szerepét emelik ki, és ennek rendelik alá a különböző gazdasági intézményeket.

A tanulás elsődlegessége a gazdasági intézményrendszerben az externália fogalmának újszerü kezelésében is megmutatkozik. A szerzőpáros azt állítja, hogy az állam szerepe a tanuló társadalom megteremtésében a negatív externáliák megakadályozása (39. o.), ez a gondolat azonban talán mélyebb annál, ahogy azt a szerzők elemzik. Az externália, akár negatív, akár pozitív a piac szabályozásának új fogalmi kerete. Az externális hatás felismerése és kezelése azonos a bölcsesség, a tudás vezetö szerepével a gazdasági döntéshozatalban. Azt jelenti, hogy a gazdasági döntések mindenoldalú hatásainak felismeréséhez létezik egy olyan intézményrendszer, amelyik csak és kizárólag a tudásra helyezi a hangsúlyt, és ezt a szempontot következetesen érvényesíti. 
Ez az intézményrendszer az állam, hiszen a piac szabályozása révén lehet az externáliákat internalizálni. Ez valójában egy új állam koncepció, amennyiben az állam szerepét nem csak az újraelosztásban, és az így felfogott, osztó igazságosságban látja.

Stiglitz híres tétele, amit e könyvben is meg lehet találni, a piacért és a piacon folyó verseny közötti megkülönböztetés ezáltal új értelmet nyer, hiszen a piac teremtése, az innovációs folyamat terelése az állam, mint tudásalapú intézmény eredménye. Szemben a korábbi felfogással, ami szerint a piac szabályozásának lényege a profitok elvonása és újraelosztása, az externális hatások kezelésére vonatkozó piacszabályozás az innovációs folyamat, azaz a tudás terjedésének alárendelt piacszabályozást jelenti. Greenwaldnak és Stiglitz-nek igaza van abban, hogy Schumpeter álláspontja meghaladható ebben a tekintetben. Schumpeter amellett érvelt, hogy a vállalatok maguktól alakítják ki piacaikat, de az innovációs folyamat fö mozgatója nem a kis, hanem a nagyvállalat, az ő szabadságuk a fejlődés mozgatórugója. [Schumpeter, 1912/1934] Greenwald és Stiglitz amellett érvelnek, hogy a vállalatok nem maguktól alakítják ki az új piacokat, az innováció nem lehet spontán folyamat, az ellentmondana a tudás fogalmának.

Ezzel cáfolják Hayek tételét is, hogy a tudás nem központosítható, pedig ez az elmúlt évtizedekben jelentős szerepet játszott a közgazdaságtudományi gondolkodásban. [Hayek, 1941] Ezzel szemben az ókori bölcsesség is azt közvetíti, hogy a tudomány hierarchikus, de a tudományon és a tudáson alapuló hierarchia az egyetlen, ami az igazságosságon és az értékrenden alapszik. Szókratész híres tétele, csak azt tudom, hogy mit nem tudok, csak kiindulópontja a klasszikus görög filozófiának. Szókratész ezzel normát állított az állam elé, a tudás keretének tekintette. Követői, Platón és Arisztotelész ezt bontotta ki azzal, hogy a tudás és a tudományok szerkezetét, hierarchiáját és rendjét felvázolta. Greenwald és Stiglitz ezt a fordulatot eleveníti fel a gazdaságelméletben, és ez egy új állam-piac-vállalat szerkezet felé tett elmozdulás.

Schumpeter-nek és részben Hayek-nek a maga korában persze igaza volt: az akkori technikai-gazdasági viszonyok és a széttagolt állami struktúra valóban nem volt alkalmas az externális hatások helyes kezelésére. Akkor még nem lehetett következetesen megfosztani az államot a provincializmustól. Az elszigetelt tulajdonviszonyok ellentmondanak az externáliák hatékony kezelésének, azok még konzerválják a provincializmust és ez a fejlődés gátja. Csak globális keretek között lehet következetesen és helyesen szabályozni a piacokat, és ez a globális kormányzás müködésének egyik formája.

\section{A DINAMIKUS KOMPARATÍV ELŐNYÖK ELMÉLETE}

A globális kormányzás egésze nem tárgya a könyvnek, ami nem elhanyagolható probléma, hiszen nem lehet elszakítani a biztonságpolitikát, a katonapolitikát, a tudományos együttmüködést és a gazdaságpolitikát. Greenwald és Stiglitz ebből voltaképpen csak egy területet elemez, a szabadkereskedelmet, ami persze rendkívül aktuális terület.

Greenwald és Stiglitz egyetértenek azzal, hogy a komparatív előnyök tana az alapja a világkereskedelemnek, ami azt jelenti, hogy minden országnak érdemes részt vennie a világkereskedelemben, és fordítva, a vezető országoknak érdemes arra törekednie, hogy minden országot bekapcsoljanak a világkereskedelembe. A klasszikus politikai gazdaságtan ismert tétele a komparatív előnyökről ezt a gazdaságpolitikai törekvést támasztotta alá. Az 1817-ben David Ricardo által megfogalmazott tézis egyrészt igazolta a brit gyarmati terjeszkedést gazdaságpolitikai oldalról, másrészt egy olyan, szabadkereskedelmi alapú kontinentális politikai egységesítésre törekedett, 
ami voltaképpen alternatívája volt a napoleoni rendszernek, és kiegészítette a Szent Szövetséget. Ricardo modellje azt az üzenetet hordozta, hogy nem szükséges katonai jelenlét a kontinens egységének biztosításához.

Ricardo elméletét sokan bírálták a későbbiekben, ami részben megalapozottnak tekinthető jelenlegi tudásunk alapján, hiszen az ő szabadkereskedelmi koncepciójába még belefért a gyarmatgyarmattartó viszony is. [Marx, 1963] Annyiban azonban Ricardo elmélete érvényesnek tünik, hogy a komparatív elönyök elmélete a globális kormányzás egyik lehetséges kerete, a tőke bevonása a globalizációba, aminek egyik oldala a kereskedelem szabályozása, alakítása. Már maga Ricardo sem írt korlátlan szabadkereskedelemről, „A külkereskedelemről” szóló fejezet jelentős része a komparatív előnyök kihasználásához és müködtetéséhez szükséges pénzügyi viszonyok kialakításáról szól. [Ricardo, 1991] A bankrendszer, a váltómechanizmus pedig már akkor is a gazdaságpolitikai intézményrendszer része volt. Fontosabb azonban a reálgazdasági aspektus, amit Ricardo ebben a formában tételesen nem említ, a komparatív előnyök kihasználásához szükséges infrastrukturális beruházások. Vasút, gőzhajózás, csatornák és az ehhez kapcsolódó kommunikációs infrastruktúra nélkül nincsenek komparatív előnyök, és a magyar reformkor vagy Széchenyi törekvései is azt mutatják, hogy ezek megteremtése gazdaságpolitikai erőfeszítéseket igényelt.

A szabadkereskedelem ezért nem általános kategória, hanem mindig konkrétan, az adott világpolitikai és világgazdasági formának alárendelt. Ebből a szempontból van jelenleg egy formaváltás a globalizációban, a globális intézményrendszerben, és a szerzők ezt fejezik ki a dinamikus komparatív elönyök elméletével. Hosszan érvelnek amellett, hogy a statikus komparatív elönnyel szemben a dinamikus komparatív előnyökre koncentrálni. A dinamikus komparatív előny a jövőbeli komparatív előny, aminek a kifejlesztésére kell koncentrálnia a gazdaságpolitikának és az iparpolitikának. A statikus komparatív előny a nemzetközi munkamegosztás jelenlegi szerkezetébe illeszti az adott gazdaságot, a dinamikus komparatív előny ezzel szemben a világgazdaság jövőbeli szintjére koncentrál, ahhoz igazodik.

A dinamika fogalma feltételezi a fejlödést és annak tervezését, a globális kormányzást és azt, hogy ebben be van vonva minden nemzetállam, régió, területi egység. Nemcsak abban a formában, hogy exportálhat és importálhat, hanem oly módon is, hogy saját állami vagy vállalati szintű tervezésének része a globális kormányzás ismerete és az abban való részvétel. Ez a radikális fordulat a korábbi komparatív előnyök elméletéhez képest. Azt az elmúlt 30 évre vonatkozóan klasszikus módon Krugman és Obstfeld fejtette ki Nemzetközi közgazdaságtan című tankönyvében. Ök lényegében a komparatív előnyök kereslet-irányította szabályozását fejtették ki. [Krugman-Obstfeld, 2006] Greenwald és Stiglitz ezzel szemben a egy globális technológiapolitika és globális gazdaságpolitikai tervezés mellett érvel, és a részvétel ebben jelenítődik meg a dinamikus komparatív előnyökben.

Az egyes országoknak (vállalatoknak és gazdálkodóknak) a világpiaci kereslet alakulása szerint kellett meghatározniuk saját külkereskedelmi potenciáljukat. Ezt a keresletet lehet tervezni, fel lehet mérni, de nem lehet befolyásolni, ebből a szempontból adottságként kell rá tekinteni. Ez az elméleti keret egészen konkrétan alkalmazható az elmúlt harminc év világkereskedelmi modelljére: lényegében az Egyesült Államok belső piaca szívta fel a világkereskedelmet, alakította a nemzetközi munkamegosztást. Ez a belső piac, annak fejlödése nem vezethető le az amerikai belső viszonyokból, vagy a szúk értelemben vett amerikai érdekekből. Amerika nem birodalmat épített, hanem a globális stabilitás és mobilitás szempontjából alakította a nemzetközi munkamegosztást. Ez azonban alulról láthatatlan volt, és ennyiben érvényes Adam Smith metaforája. 
Kézként müködött, azaz alakította, befolyásolta a gazdálkodókat, nemzetállamokat, de azok nem láttak bele, és kevéssé vettek részt a folyamatban. Ez nem önkényes döntés volt az USA részéről, inkább arról van szó, hogy nem volt eléggé jelen a világ többi országában a globális értékrend iránti elkötelezettség. Ennek tagoltságáról, szerkezetéről Henry Kissinger írt például a „Korszakváltás az Egyesült Államok külpolitikájában?” címü munkájában. [Kissinger, 2002]

Napjainkban azonban jelentős eltolódás megy végbe ebben a szerkezetben, és ezt fejezi ki a dinamikus komparatív előnyök elmélete. Ennek lényege, hogy minden ország gazdasági fejlődését, iparpolitikáját tudatosan a tanulásnak, azaz a tudásalapú gazdaságnak rendelik alá, és ebben van globális együttmüködés az országok, regionális szervezetek között világszinten. Stiglitz példája szerint, ha Dél-Korea csak a statikus komparatív előnyök szerint határozta volna meg gazdaságpolitikáját, akkor még mindig rizst termesztene, és nem lenne autóipara, gépgyártása, vagy Brazília nem rendelkezne repülőgépiparral. Ami ezt a két országot kiemelte, az a tudatos iparpolitikai fejlesztés volt, a dinamikus komparatív előny felismerése és kiaknázása. A példákhoz csak azt lehet hozzátenni, hogy ezek egyrészt azt igazolják, hogy az elmúlt harminc évben is olyan világkereskedelmi rendszer alakult ki, amelyik végső soron segítette a fejlődést, egyes országok felzárkózását, de kétségtelen, hogy nem teljesen átlátható módon. Dél-Korea esetében nem lehet elfelejtkezni a japán és az amerikai szerepvállalásról, amelyik piacot biztosított a fiatal vállalatoknak, Brazília esetében pedig az amerikai vállalatok kiszervezési hullámáról. Dél-Korea esetében az iparosítási folyamat stabilizálta Japán és Kína viszonyát, míg Brazília egy új, a populizmust visszaszorító latin-amerikai modellt képviselt.

Tagadhatatlan, hogy az elmúlt harminc évben a dinamikus komparatív előny megteremtésének fő formája az outsourcing volt, amit azért nem lehet egyszerűen azonosítani a „piszkos”, környezetszennyező iparágak kihelyezésével (noha volt ilyen eleme). Ez inkább egy sajátos iparpolitika volt, felzárkóztatás, egy új munkakultúra átadásának formája, ami valóban emlékeztetett néhány elemében a klasszikus kapitalizmusra. Ennek keretében valóban jelen volt az a felfogás, hogy a tanulás lényege a géphez való alkalmazkodás, nincs szükség elkülönült tanulási folyamatra, intézményekre, szervezésre. A felfogáshoz tartozott, hogy a hatékonyság előbbrébb van a társadalmi és a természeti harmóniához képest, a társadalmi kötelékek csak korlátozzák a fejlödést. Nem lehet azt állítani, hogy ez a közelítés teljesen alaptalan lett volna az elmúlt harminc évben. Sok esetben csak így lehetett leküzdeni a XX. századi provincializmust. Amit azonban ma tapasztalunk az ennek a szemléletnek a meghaladása, egy új intézményi rend létrehozása a társadalmi és természeti harmónia érdekében globális keretek között.

A dinamikus komparatív előnyök elmélete ezért nem abban új, hogy iparosítási programot valósít meg az agrárországokban, hanem abban, hogy az egyes állami, regionális és vállalati szintü iparosítási programokat összehangolja, a tervezési folyamatot demokratizálja. Ennek a tervezésnek van keresleti és kínálati összefüggése, de az úgynevezett belső piacra támaszkodó növekedés (ami gyakran elökerül a hazai növekedési koncepciókban), nem a provincializmus konzerválását jelenti, hanem a belső és külső piac nagyobb összhangját.

\section{A „FIATAL GAZDASÁG” ÉS AZ IPAR-MEZŐGAZDASÁG VISZONY}

Ez magyarázza, hogy Greenwald és Stiglitz érve a „fiatal gazdaság” mellett miért ennyire fontos. Kritizálva a „fiatal iparág” modellt, nem támogatják az ágazati szintű protekcionizmust, de elfogadhatónak tartják a „fiatal gazdaság” védelmét. A különbség álláspontunk szerint a globális 
kormányzásba való bekapcsolódás módja. A „fiatal iparág” érvet a közgazdaságtudomány régóta ismeri, lényege, hogy egyes iparágakat védelemben kell részesíteni, amíg meg nem erösödnek ahhoz, hogy fel tudják venni a versenyt a legfejlettebb országok iparaival. A „fiatal iparág” érv alapja, hogy a fejlett iparral rendelkező ország arra használja előnyét, hogy kizsákmányolja, elnyomja, fejlödésében akadályozza a kevésbé fejlettet. Politikai, gazdaságpolitikai érdek ennek megakadályozása, és ebben minden eszköz megengedett.

Bár sokféle előzményét lehet találni ennek a gazdaságpolitikának, de a közgazdaságtudományban leggyakrabban Alexander Hamiltont szokták említeni, aki a születő Egyesült Államoknak azt javasolta, hogy túlélése érdekében védje meg iparát a britekkel szemben, mert Nagy-Britannia csak gyarmati uralmát akarja fenntartani technológiai-gazdasági eszközökkel. [Hamilton, 1791]

Sokan érvelnek amellett, hogy Kína vagy Oroszország sem tesz mást jelenlegi kereskedelempolitikájában, mint amit Hamilton javasolt az USA-nak 1791-ben. Ezt az álláspontot nem osztjuk, mert az USA-nak a XX. században soha nem volt célja, és ma sem az, hogy kizsákmányoljon egyes országokat, de az igaz, hogy jelenleg egy formaváltáson megy keresztül fejlödésük támogatása, részvételük a globális gazdaságpolitikában. Az új forma egyik eleme a „fiatal gazdaság” érv, ami lényegében a jövőre orientáltságot, a tanulási folyamatba való bekapcsolódást jelenti, és ennek a tanulásnak a támogatását. A „fiatal iparág” érvnek mindig az volt a hátulütője, hogy ezzel provinciális, alacsony termelékenységü termelést is támogattak, és nehezen lehetett meghatározni, hogy mikor nőtt fel már az iparág. A „fiatal iparág” érvet gyakran vetették el azzal, hogy jövőorientáltságot állítja a középpontba, hiszen ettől lesz egy gazdaság fiatal. A jövőorientáltság eléréséhez, az innovációk befogadásához pedig olyan ösztönzőket használ, amelyek a tanulást és csak a tanulást segítik. Nem vámokról és kereskedelmi akadályokról van tehát szó, amelyek eltérítik az optimumtól a fogyasztói és a termelöi döntéseket, hanem az optimalizációs folyamat olyan alakításáról (például a szabályozás során vagy a preferencia-rendezés és a hasznosság meghatározása kapcsán), ami a tanulási folyamatot támogatja. Ma már sokféle ilyen eszköz létezik, ebből a szempontból a viselkedés-gazdaságtan jelentős eredményeket produkált.

Greendwald és Stiglitz szakítani akar a XX. század fejlődéselméletével és fejlesztéspolitikájával, ugyanakkor bizonyos szempontból tovább is gondolható érvelésük. Véleményük szerint az „az ipar az innováció forrása" (115. o.), és ennek dominanciáját kell támogatni a mezőgazdasággal szemben. Álláspontunk szerint a fejlődés nem egyszerüsíthető le az ipar és a mezőgazdaság szembeállítására, ma már egyre kevésbé tartható az, hogy az ipar hordozza a fejlődést a mezőgazdasággal szemben. Az az állítás igaz, hogy „az iparpolitikák egyik célja a másoktól való tanulás megkönynyítése" (76. o.), de ehhez az infrastruktúra és az ipar fogalmát érdemes elválasztani egymástól.

Kétségtelen, hogy különösen az első ipari forradalom óta az ipar hordozta a tanulási folyamatot. Az is igaz, amit a szerzők megállapítanak, hogy ennek oka az ipari termelés nagy mérete, a termékek tartóssága, a termelés földrajzi mobilitása volt. Ezek az előnyök azonban a modern információs technikával egyre inkább elvesznek. A távérzékelés, az ürtechnika fejlődése egyre inkább lehetővé teszi, hogy az elszigeteltség, és a rossz értelemben vett függetlenség a termelési folyamat egyetlen elemében sem maradjon fenn. A Föld egészére kiterjedő élelmiszerbiztonsági követelmények, vagy a különböző környezetkárosító tevékenységek elleni globális fellépés ennek különbözö technológiai és intézményi kereteit valósítják meg. Ma már nem szükséges fizikailag összegyüjteni a gazdálkodókat ahhoz, hogy egységesen lehessen irányítani, nyilvántartani és ellenőrizni őket. A modern, ürtechnológiai infrastruktúra globális szintű termelés- és fogyasztásirányítást tesz lehetővé, és ez a legfontosabb technológiai fejlődési irány. 
$\mathrm{Az}$ infrastruktúra kiterjedése és globális érvényesülése teszi lehetővé a szüken vett ipari tevékenység decentralizálását, a 3D technológiák és a robothasználat elterjedését. Megszűnik a mezőgazdaság parcella-jellege, és a mezőgazdasági termelést meghatározó ellentét a nagyüzemi és a kistermelés között. Az infrastruktúra segítségével a kistermelök is nagyüzembe szervezhetők abban az értelemben, hogy termelési folyamatukban nem vétenek az élelmiszerbiztonsági követelményekkel vagy a hosszú távú fenntarthatósággal szemben. Ugyanakkor a nagyüzem is átalakul, amennyiben a monokulturális termelés átalakulófélben van, egy sokszínúbb, a helyi adottságokhoz jobban igazodó, ökológiai alapú mezőgazdasági termelés van kialakulóban. Ehhez a mezőgazdasági átalakuláshoz igazodik az ipar, és ez az oka annak, hogy egyre kevésbé van szükség az ipari tevékenységhez a különböző erőforrások fizikai koncentrációjára.

$\mathrm{Az}$ ágazati átrendeződés felveti a tanulás fogalmának finomítását. Az iparon alapuló tanulás egyik meghatározó összefüggése volt az a fajta kényszer, amit az ipari technológia hordozott. A gép és a géphez kötődő technológia kényszerítette ki a tanulást, és lényegében a gép mérete és müködése határozta meg az üzem és a vállalat méretét, ezen keresztül a tanulási folyamatot is. Ezzel szemben napjainkban a gépnek ez a szerepe átalakulóban van. Egyre kevésbé beszélhetünk elszigetelt gépröl, sokkal inkább az egységes és globális szintü infrastruktúrához való hozzáférés alakítja a termelést és a fejlődést, és ezért lehet bizonyos mértékü decentralizálódásról beszélni. Az egyik oldalon globális szintű centralizálódás megy végbe, míg a másikon tapasztaljuk a területi kiegyenlítődést a szükebben vett termelési folyamatban. Nem érvényes már az a tétel, hogy a mezőgazdasági provincializmust az iparosítással lehet felszámolni. Inkább az érvényes, hogy ipar és mezőgazdaság összekapcsolódik az infrastruktúra és a szolgáltatások révén.

A szolgáltatásnak az a sajátossága, hogy erőteljesebben érvényesül benne a hosszú távú kapcsolat, megszünik vagy legalább is háttérbe szorul a gazdálkodók közötti tárgyi közvetítés, és ebből fakadóan egy elidegenedésmentes hierarchia tud kialakulni a szolgáltatásalapú gazdaságban. A szolgáltatás keretében lehet meggyőzni az ügyfelet az új technika használatáról, egy másik gazdálkodási minta követéséről, a szolgáltatás közvetlenül a kultúra átadása nem tárgyi alakban. A szolgáltatás az automatizáció korában nem csak egy elkülönült ágazat, hanem egyre inkább minden más ágazatot is átfogó elem. Minden termék bele van építve egy információs tömegbe, szolgáltatáscsomagba, legyen ez a garanciavállalás vagy az adalékanyagok felsorolása az élelmiszerben. Minden gazdasági tevékenység szolgáltatási tartalma kerül a középpontba, és az „iparpolitikának” ezt a tendenciát kell erősítenie, ezért tekinthetjük a szolgáltatásokat húzóágazatnak.

\section{Politikai gazdas ágtan és Vállalatelmélet}

Greendwald és Stiglitz müvének az egyik fő érdeme, hogy az ágazati politikát visszahelyezi jogaiba, a neoliberális szemlélettel szemben újra hangsúlyozza a technológiapolitika és az ágazati politika fontosságát. A kötet a XXI. század követelményeihez igazodik azzal, hogy a technológiapolitika és ágazati politika fó eszközének a szabályozást, és nem a költségvetési támogatást tekinti. A XX. századra volt jellemző, hogy a fö iparpolitikai eszköznek a költségvetési támogatást tekintették, és ez versenytorzító lehet, nem vagy nem feltétlenül van összhangban a teljesítményelvvel. A neokonzervativizmus-neoliberalizmus kritikája ebben a tekintetben a Keynes-i típusú beavatkozással szemben helytállónak tekinthető.

A XXI. század közgazdaságtanának az a jellegzetessége, hogy a szabályozást és a technológiát hozza összhangba, és Greenwald és Stiglitz erre az összefüggésre hívja fel a figyelmet. A technológiai 
követelmények, a szabványok kialakítása a meghatározó eszköz, és ezzel is érvényesíteni lehet a közjót. Ebben a tekintetben fel is lehet vetni egy másik szempontot Stiglitz-éké mellett, az eredményességet. A szabályozás megítélése során Greenwald és Stiglitz talán túlságosan csak a hatékonyságot tartják szem előtt, és azt nem, hogy a szabályozás tárgya az a szükséglet is, amit a vállalat kielégít.

A szükséglet abban az értelemben nem egyéni preferencia kérdése, hogy összhangban van-e az értékrenddel vagy nincs. A XXI. században már egyetlen állam számára sem közömbös a droghasználat vagy az alapvető közjavak biztosítása. Nem egyéni preferencia kérdése a víz-, a csatorna vagy az áramellátáshoz való kapcsolódás. Van olyan terület, ahol az állam semlegessége megmaradhat, de általános elvként ez a tétel már nem szolgálhat a szabályozási folyamatban. Az ismét csak ez elmúlt időszak elméleti problematikusságához tartozik, hogy erről kevés szó esett a közgazdaságtudományban, bár a gyakorlatban nem került háttérbe. Az új típusú szabályozás nem mond ellent a fogyasztói szabadságnak, nem veszi ki a döntést a fogyasztó kezéből, olyan módon ösztönzi a fogyasztót, hogy a szabadság tartalma az értékrend önálló alkalmazása legyen.

Az önállóság konkrétan a közjó érvényesitését jelenti, ezért a közjó fogalma újra a közgazdasági gondolkodás középpontjába kerül. A közjó meghatározása gazdaságpolitikai feladat, és ebből lehet levezetni a piaci szabályozást. Közjó lehet a klímaváltozás megakadályozása, lehet közjó a széndioxid-kibocsátás csökkentése vagy akár a műanyagok használatának visszaszorítása. Ezek kijelölése azonban ugyanolyan tudományos feladat, mint ezek meghatározása után a konkrét piaci szerkezet levezetése. Ez a legszűkebben vett politikai gazdaságtan feladata.

A politikai gazdaságtan az egyetlen értékrendet alkalmazza a gazdaságra, ennek első lépése a közjó és a közjószág meghatározása. Azok a viták, amelyek napjainkban például a klímaváltozás mérsékléséről szólnak, nemcsak azt vetik fel, hogy mérsékelni kell a környezetszennyezést, hanem azt is, hogy a használt eszközök mennyiben felelnek meg az értékrendnek. A közjó jövőkép is, politikai-gazdaságpolitikai perspektíva, amit ma már csak globális keretek között lehet meghatározni. A technológiapolitika és az ebből fakadó szabályozás ezért alapvetően globális szinten hatékony. Ebből a globális intézményrendszerből, amit globális kormányzásnak nevezünk vezethető le az összes többi szabályozási szint is.

Greenwald és Stiglitz könyvének egyik legföbb érdeme az az elméleti keret, ami a vállalati szektort hatékonyan kapcsolja be a fejlesztéspolitikába. A szerzők hosszan érvelnek amellett, hogy a piacszabályozás célja nem a tökéletes verseny, hanem az innovációt szem előtt tartó nagyvállalat. Ezzel a közelítéssel meg is haladják az elmúlt harminc-negyven év piacszabályozási elméletét (de nem piacszabályozási gyakorlatát). A lényegében Stigler által sikerre vitt versenypolitikai keret lényege a tökéletes verseny feltételeinek biztosítása volt. [Stigler, 1989]

Stigler amellett érvelt, hogy a deregulálás, az információk megosztására való ösztönzés illetve törvényi kényszerítés, vagy a viszonylag laza engedélyezési folyamat elegendő a hatékony piac müködéséhez. Stiglernek a saját korában igaza volt abban, hogy az átláthatatlan, a provinciális politikai és technológiai viszonyokat konzerváló, elkülönült piacszabályozással szemben a világpiaci verseny hatékonyabb forma. Igaza volt a konkrét gazdaságpolitikai irányban is, hiszen végső soron a nyugati multinacionális cégek térnyerését támogatta. Ezek a vállalatok fejlettebb müszaki és gazdálkodási kultúrát exportáltak a fejletlenebb országokban. Ez a terjeszkedési korszak azonban lezárult lényegében a 2008-as válság óta, és a deregulációval szemben egy új típusú, globális szintủ reguláció jelenik meg. Ez azonban azzal a következménnyel jár, hogy a korábbi versenypolitikát felülbírálják, és tudatosan egy olyan hierarchikus piacszerkezetet ösztönöznek, aminek a tetején az innovatív nagyvállalat áll. 
A neokonzervatív-neoliberális modellben elmélet és gyakorlat szemben állt egymással. Beszéltek a versenypolitikáról és a monopóliumok alacsony hatékonyságáról, de a gyakorlatban a multinacionális vállalatok uralták a piacokat. Ez a versenypolitika gazdaságpolitikai tartalmát tekintve a helyi, provinciális monopóliumok ellen irányult anélkül, hogy világosan kifejezte volna ezt, a globalizációval összhangban levő irányt. Ezt az ellentmondást a szakirodalom régóta tárgyalja és kritizálja, nevezetesen, hogy tökéletes versenyről beszélnek, miközben a gyakorlatban végső soron globális szintű oligopol szerkezet van. Erre az ellentmondásra ad választ Greenwald és Stiglitz azzal, hogy egyértelmúbb politikai gazdaságtani és piacszabályozási irányt javasol, amihez tudnak kapcsolódni az innovatív nagyvállalatok. Stiglitz-ék is elfogadják Schumpeter elméletét: az innováció forrása a nagyvállalat, és nem a sok kisvállalat. A nagyvállalatnak van annyi jövedelme és piaci ereje, hogy képes legyen hosszú távon finanszírozni kutatásokat és fejlesztéseket, képes legyen az innovációt a piac meghatározó szempontjává tenni.

A nagyvállalat nem azonos a monopóliummal, a különbség a kettő között az innovációra való hajlam. Greenwald és Stiglitz könyvének legérdekesebb részei tárgyalják azt, hogyan, milyen ösztönzési eszközökkel lehet elválasztani egymástól a két típusú vállalatot - hiszen erre a vállalat mérete nem alkalmas. Amit ehhez hozzá lehet tenni az egyrészt módszertani kérdés: az eredményességet, azaz az összhangot a közjóval a hatékonyság mellett érdemes részévé tenni a szabályozásnak.

A másik szempont a vállalat fogalmára vonatkozik, amit Greenwald és Stiglitz implicite magáévá tesz. Eszerint az innovatív vállalatra igaz, hogy közösség a közjó érvényesítésére egy adott ágazatban, gazdasági területen. Nem a munkás kizsákmányolásának az eszköze, ahogy azt a vulgármarxizmus vagy a neoliberalizmus is elfogadta (csak hol a munkás, hol a tőkés oldalára álltak), hanem civil szervezet, aminek alapja a vállalatban együttmüködők közös kultúrája, közös műveltsége. Az értékrend alkalmazására alkotnak közösséget. Ezt tükrözi a magyar vállalat név is, hiszen tagjaik közösen vállalnak valamit a közjó, a köz igényeinek kielégítésére. A vállalat ettől lesz tanulási közösség, hiszen végső soron a barátság az alapja, márpedig a barátok egymásban a jót szeretik, az ókori bölcselet meghatározása alapján. A vállalat pedig egy lehetséges formája a barátság gyakorlásának és müvelésének.

A vállalat ebből fakadóan láthat el közfunkciókat, és ilyen közfunkció egy bizonyos társadalmi szükséglet kielégítése. Ez a szükséglet értékrendi, kulturális és fiziológiai szükséglet egyben. Nem csak az evés-ivás kényszeréről van szó, hanem a fizikai szükségletek olyan kielégítéséről, ami az értékrendet érvényesíti a közjót szolgálja. Ennek a feladatnak az ellátásához van szükség erőforrásokra, és ennek a tevékenységnek a díja a profit. A profit tehát nem a kizsákmányolás eredménye, hanem az együttmüködés díja, amit vissza lehet forgatni az együttmüködés erösítése érdekében. Greenwald és Stiglitz ezért tartja elfogadhatónak a profitot, tud elképzelni olyan piaci modellt, amiben tartósan fennmarad a profit. Ennek intézményi feltétele állam és vállalat összhangja, a köz- és a magántulajdon hierarchiája.

Erre a vállalati modellre csak akkor van lehetőség, ha a termelési tevékenységben megszűnik a fizikai, szolgai jellegü munka kényszere, és ez egy olyan technológiai elem, aminek a feltételei tömegesen csak a XXI. században jelentek meg. Az automatizáció és a robottechnika korában valóban elképzelhető már, hogy a rutinmunka csak a gyakorlottság betanításáról szól, ez a tanulás kényszere, és nem a szabadságtól való megfosztás. Ma már igaz lehet, hogy az együttmüködés az értékrend következetes alkalmazásán alapszik, és nem kell elvtelen kompromisszumokat kötni a teljesítmény érdekében. A mai technika alapján a teljesítményelv csak és kizárólag az értékrend érvénesítéséről szól, és ez valóban ugrás a vállalat intézménye számára. 
Az új vállalatmodell megteremtéséhez piaci, társadalmi feltételek is kellenek, olyan közeg, ami ezt támogatja. Greenwald és Stiglitz ezt a sajátos „mozgalmi” funkciót is említi, kétségtelenül kevésbé modellezi. Ök a szabályozási-igazgatási elemre koncentrálnak, de tisztában vannak azzal, hogy a várakozás a harmonikus ágazati rendre, az új világrend müködésére elengedhetetlen feltétele az új modell érvényesülésének.

A kötet végén jeles közgazdászok füztek kommentárt a tanulmányhoz. Egyikük, Kenneth Arrow így fogalmazott: „A tudás ingyenes. A legnagyobb költség, amely a továbbadása során felmerül, nem a tudás előállításával, vagy elosztásával, hanem a befogadásával kapcsolatos. Ezt minden tanár tudja. A kereskedelem egyik előnye, hogy elősegíti a technológiai tudással kapcsolatos információk elterjedését. A kapcsolat megléte - az eszmék áramlanak - tovagyürüző hatásokhoz, tanuláshoz és erősebb versenyhez vezet.” (548. o.) A globális kormányzás egyik célja a magaskultúrák egyesítése, és ehhez a jól szervezett világkereskedelem, és benne a tanulásra ösztönző szervezetek, vállalatok elég jó eszközök. Ez az üzenete Greenwald és Stiglitz mủvének.

Trautmann László ${ }^{2}$

\section{Felhasznált IROdAlom}

Arisztotelész: Metafizika (fordította és kommentárokkal látta el Ferge Gábor), Logos Kiadó, Budapest, 1992

DEATON, Angus. The great escape: health, wealth, and the origins of inequality. Princeton University Press, 2013.

FOGEL, Robert William. The escape from hunger and premature death, 1700-2100: Europe, America, and the Third World. Cambridge University Press, 2004.

HAMILTON, Alexander. Report on Manufacturing. American State Papers, Fi-nance (Washington, DC, 1832), I, 1791, 123-44.

HAYEK, FA v. The counter-revolution of science. Economica, 1941, 8.31: 281-320.

KISSINGER, Henry. Korszakváltás az amerikai külpolitikában. Panem-Grafo, Budapest, 2002.

KRUGMAN, Paul R. - OBSTFELD, Maurice - MELITZ, M. International economics: Trade and policy. 2006.

MARX, Karl. Értéktöbblet-elméletek. Kossuth Könyvkiadó, Budapest, 1963.

RICARDO, David - DÉNES, Kislégi Nagy. A politikai gazdaságtan és az adózás alapelvei. Közgazdasági és Jogi K., 1991.

Schmidt, Helmuth (Hg.): Vertiefungen. Neue beiträge zum Verständnis unserer Welt, Siedler Verlag, München, 2010

SCHUMPETER, Joseph A. The Theory of Economic Development: An Inquiry into Profits, Capital, Credit, Interest, and the Business Cycle (1912/1934). Google Scholar, 1961.

SEN, Amartya. Freedom as development. Oxford: Oxford University Press, 1999.

STIGLER, George J. Piac és állami szabályozás. Közgazdasági és jogi Könyvkiadó, Budapest, 1989.

\footnotetext{
${ }^{2}$ egyetemi docens, Mikroökonómia Tanszék, Budapesti Corvinus Egyetem
} 